\title{
EFFECT OF TRADITIONAL PROCESSING STEPS ON CHEMICAL AND NUTRITIONAL COMPOSITION OF LEBLEBI
}

\author{
F. ÖZвEY* \\ Department of Food Engineering, Engineering Faculty, Hitit University, TR-19030, Çorum. Turkey
}

(Received: 28 May 2015; accepted: 20 July 2015)

\begin{abstract}
Turkey's and several Middle East countries' people consume "leblebi", which is a traditional snack food made from chickpea (Cicer arietinum L.). Leblebi processing steps caused significant decrease $(\mathrm{P}<0.05)$ in moisture and carbohydrate fractions. The dietary fibre contents were also reduced through leblebi processing steps. Dehulling process caused reduction in cellulose from 2.6 to $1.3 \%$, whereas increase in acid detergent lignin content from 0.27 to $0.85 \%$ was observed. The mineral analysis results have shown that leblebi samples supply macro and micro nutrients required in the human diet.
\end{abstract}

Keywords: chickpea, ethnic food, leblebi, roasted chickpea, snack food

Legumes are consumed in different regions of the world, prepared in various ways. Next to Bengal gram dhal, red gram, a native of South-East Asia, is the most widely consumed legume in South India. There are lots of foods like Rasam, sanber, and other savoury dishes that are prepared with legumes (Tharanathan \& Mahadevamma, 2003). Chickpea (Cicer arietinum L.) is one of the world's oldest and most widely consumed legumes due to its relatively high protein content and wide adaptability (FAO, 2012).

Leblebi is a traditional snack made from roasted chickpeas common and popular in Turkey and several Middle Eastern countries. Chickpeas used for leblebi are selected for shape, size, colour, and harvesting time. Generally large seeded (5-9 $\mathrm{mm}$ in diameter and 25.0-50.0 g of 100- kernel weight), lighter coloured, round and smooth surfaced Kabuli chickpeas are preferred (KÖKSEL et al., 1998; CoşKUNER \& KARABABA, 2004).

There are mainly two different kinds of leblebi as dehulled (yellow leblebi) and nondehulled (white leblebi) traditionally produced from chickpeas in different parts of Turkey. Today, leblebi is produced traditionally at family plants. Producers try to increase product diversity by coating leblebi with salt, capsicum, chocolate, sugar, sesame, and cloves at the final roasting stage. Furthermore, leblebi has a potential use as a natural "functional food" due to its chemical composition. It has high protein, cellulose, and mineral content, and is low in fat. Its low glycemic index (GI) makes leblebi a great snack compared to sugary or high GI snacks. Because of the low moisture content, leblebi has long shelf life. If appropriate packaging materials are used, it can be stored for 6 to 12 months. The present study was aimed at evaluating the effect of traditional processing steps on the nutritional composition of chickpea seed.

* Phone: +90-364-227 45 33; fax: +90-364-227 45 35; e-mail: fatihozbey@hitit.edu.tr 


\section{Materials and methods}

\subsection{Materials}

Raw chickpea seeds and leblebi samples were obtained from Gülşen Leblebi Company, which is one of the oldest local processors of Çorum, Turkey.

\subsection{Leblebi processing steps}

Conversion of raw chickpeas to leblebi takes approximately one month and a half. The chickpeas are sorted by size before tempering and resting processes. Tempering takes place at $85-90{ }^{\circ} \mathrm{C}$ for 10 to $15 \mathrm{~min}$ for penetration of moisture into the structure. After tempering, there is a long resting phase, which takes nearly 30 days at ambient temperature. Chickpeas are kept in jute bags during resting stages. This resting stage is the most important in leblebi quality, being responsible for the development of organoleptic changes expected in roasted chickpeas. After resting, first roasting process is applied, which peels away the shells of the chickpeas. The leblebi at this stage is known as "single roasted leblebi". These half-mature products need only a final roasting two days later to be ready for sale (KöKSEL et al., 1998).

\subsection{Proximate compositions, dietary fibre and mineral analysis}

For analysis, the samples of leblebi or chickpea were ground and passed through a $350 \mu \mathrm{m}$ mesh sieve. Proximate composition was determined by measuring the fat, ash, moisture, protein $(\mathrm{N} \times 6.25)$, and carbohydrates (by difference) contents in duplicate by standard procedures of AOAC (2000). The Van Soest detergent procedure (RzEDZICKI et al., 2008) was used to determine the content of detergent fibre fractions (neutral detergent fibre - NDF, acid detergent fibre - ADF, cellulose - CELL, and acid detergent lignin - ADL). The samples were treated using the microwave digestion technique, and the mineral composition was determined by atomic absorption spectrometry (WANG et al., 2010).

\subsection{Determination of total phenolic content and total antioxidant capacity}

Total phenolic content (TPC) was determined by the Folin-Ciocalteu reagent (SingLETON \& Rossi, 1965; Singleton \& Lamuela-Raventos, 1999) using gallic acid (GA) as standard. The TPC was expressed as GA equivalents (mg of GAE/g sample) through the calibration curve of GA.

Antioxidant activity was measured using the ABTS [2,2-azino-bis(3-ethylbenzothiazothiazoline-6-sulfonic acid) diammonium salt] method (SERPEN et al., 2007) with some modifications. All measurements were performed at exactly the $6^{\text {th }}$ min after mixing the sample with the ABTS reagent. The antioxidant activity was expressed as millimole of Trolox (6-hydroxyl-2,5,7,8-tetramethylchroman-2-carboxylic acid) equivalent antioxidant capacity (TEAC) per kilogram sample by means of a dose-response curve for Trolox.

\subsection{Statistical analysis}

All results in this study are reported as means of two replications. The data were analysed using a one factor analysis of variance (ANOVA) and Tukey mean separation for multiple comparisons with the SPSS 7.5 software. Significance was defined at $\mathrm{P}<0.05$. 


\section{Results and discussion}

Analysis of variance showed that leblebi processing steps have significant $(\mathrm{P}<0.05)$ effects on moisture, fat, ash, and carbohydrate contents (Table 1). Because of water absorption, tempering increased the moisture content of leblebi by nearly $10-30 \%$. During the resting stage, uniform moisture distribution was achieved, but at the same time desorption caused about $20-30 \%$ loss of moisture. After exposure to high temperature in roasting step, the moisture content was reduced further by $3 \%$. These reductions in the moisture content during processing were statistically significant $(\mathrm{P}<0.05)$. The present results are in good agreement with previous reports (Costa et al., 2006; IQBAL et al., 2006; КнATTAB et al., 2009).

Table 1. Effect of leblebi processing on chemical composition of chickpeas (\%)

\begin{tabular}{lccccc}
\hline Sample & Moisture & Protein & Fat & Ash & Carbohydrate* \\
\hline Raw chickpea & $10.78 \mathrm{~d}$ & $19.11 \mathrm{a}$ & $5.98 \mathrm{a}, \mathrm{b}$ & $2.54 \mathrm{a}, \mathrm{b}$ & $61.59 \mathrm{a}$ \\
1. Tempering & $7.25 \mathrm{c}$ & $19.44 \mathrm{a}$ & $6.39 \mathrm{~b}, \mathrm{c}$ & $2.60 \mathrm{a}, \mathrm{b}$ & $64.32 \mathrm{~b}, \mathrm{c}$ \\
2. Tempering & $3.05 \mathrm{a}$ & $20.44 \mathrm{a}$ & $6.85 \mathrm{~b}, \mathrm{c}$ & $2.77 \mathrm{~b}$ & $66.89 \mathrm{~d}, \mathrm{e}$ \\
Roasting & $5.38 \mathrm{~b}$ & $20.51 \mathrm{a}$ & $7.90 \mathrm{~d}$ & $2.46 \mathrm{a}$ & $63.75 \mathrm{~b}$ \\
Last roasting & $3.31 \mathrm{a}$ & $20.79 \mathrm{a}$ & $7.85 \mathrm{~d}$ & $2.49 \mathrm{a}$ & $62.13 \mathrm{a}, \mathrm{b}$ \\
(Dehulled leblebi) & & & & & \\
\hline
\end{tabular}

*Values are means of duplicate analysis. Means in the same column with different letters are significantly $(\mathrm{P}<0.05)$ different.

The protein, fat, ash, and carbohydrate contents of raw chickpea were 19.11, 5.98, 2.54, and $61.59 \%$, respectively. The results of the proximate composition are similar to the study of Milan-CARILlo and co-workers (2000), who have reported mean values for desi chickpea cultivars. The ash and carbohydrate contents were 2.49 and $62.13 \%$ for dehulled leblebi. The effects of dehulling process on ash and carbohydrate contents are in agreement with findings for chickpea by SINGH and co-workers (1992). The protein content of dehulled leblebi was $20.79 \%$. This value showed that protein content of chickpea was nearly unaffected by leblebi processing steps $(\mathrm{P}>0.05)$.

Dietary fibre is substantial in supporting of health. The Institute of Medicine defines fibre as a non-digestible food plant carbohydrate. According to the Institute of Medicine, dietary reference intake, an adequate intake for total fibre, is set at 38 and $25 \mathrm{~g}$ per day for young men (age 14-50 years) and women (age 19-50 years), respectively (USDA, 2007).

The effect of leblebi processing steps on the dietary fibres is shown in Figure 1. The raw chickpea contained $2.6 \%$ cellulose and $4.2 \%$ ADF, whereas the NDF and ADL contents were 7.4 and $0.27 \%$, respectively. These dietary fibre results showed variations from the reported values in the literature, which is quite likely due to difference in soil, fertilizers, climate, harvesting time, botanical variety, etc. Leblebi processing caused some changes in dietary fibre components, and the changes were more pronounced in dehulled leblebi. First and second phase of tempering of chickpeas caused some changes in cellulose, ADF, and NDF components (Fig. 1). However, these changes were more pronounced at first roasting on chickpeas, because dehulling occurs at this step. Tempering processes did not significantly alter ADL content on dry matter basis. It can be seen in Figure 1 that increase in ADL was only from 0.27 to $0.85 \%$ as a result of dehulled processing. The contents of cellulose, NDF, 
$\mathrm{ADL}$, and ADF significantly $(\mathrm{P}<0.05)$ changed at dehulled leblebi processing steps. In general, the observed effect of leblebi processing on individual dietary fibre components in chickpeas depended not only on the tempering steps, but also on the roasting involved. These results were also in good agreement with the findings of ReHмAN and SнAн (2004). Similar changes in dietary fibre contents of chickpeas during cooking processes were noted by other studies (Rehman et al., 2003; Rehinan et al., 2004; Costa et al., 2006).

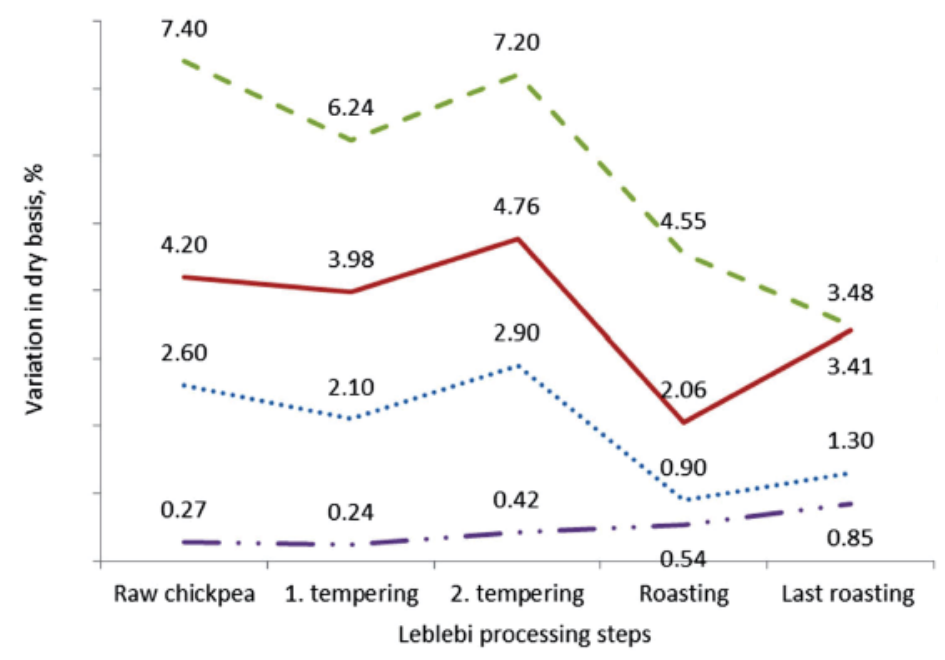

Fig. 1. Effect of leblebi processing on dietary fibres content of chickpeas, \%, dry basis $\cdots \cdots \cdot$ : Cellulose; $\longrightarrow$ : ADF; - - : NDF; — $:$ ADL

Figures 2 and 3 show the change of TPC and total antioxidant capacity of chickpeas during leblebi processing steps. The trends are similar for all of them. The early stages of processing steps are characterized by decrease. New antioxidants and phenolics are formed as a result of Maillard reaction, increasing the TPC and total antioxidant capacity at roasting steps, which in some cases restored the original TPC value. TPC of samples ranged between 0.64 and $0.72 \mathrm{mg}$ gallic acid equivalents/g. These values were lower than the concentrations reported as 4.24 catechin equivalent/100 g extract and $1.82 \mathrm{mg}$ gallic acid equivalents $/ \mathrm{g}$ (MONDOR et al., 2009; VADIVEL et al., 2011). According to literature, TPC is directly associated with antioxidant capacity. TPC of the samples showed strong positive correlations $(\mathrm{r}=+0.982)$ with the antioxidant capacity. This pattern is in agreement with the TPC and total antioxidant capacity of the samples (AÇAR et al., 2009; Cristobal et al., 2010; VEGA et al., 2010).

The antioxidant capacity of samples ranged between 16.12 and 20.43 mmol Trolox equivalent per kg (Fig. 3). Leblebi processing steps significantly $(\mathrm{P}<0.05)$ affected the antioxidant activity of chickpeas. Antioxidant compounds are naturally occurring in food generally, but they can occur also as a result of chemical reactions taking place during the thermal treatment applied on the food (GöKMEN et al., 2009). The decrease in antioxidant activity observed in the first and second tempering stages is probably due to the amount of thermally labile antioxidant compounds present in chickpeas. During roasting, slight increase 
in antioxidant activity can be attributed to newly formed antioxidant compounds through Maillard reaction. The reaction is promoted by low water content during roasting of chickpeas.

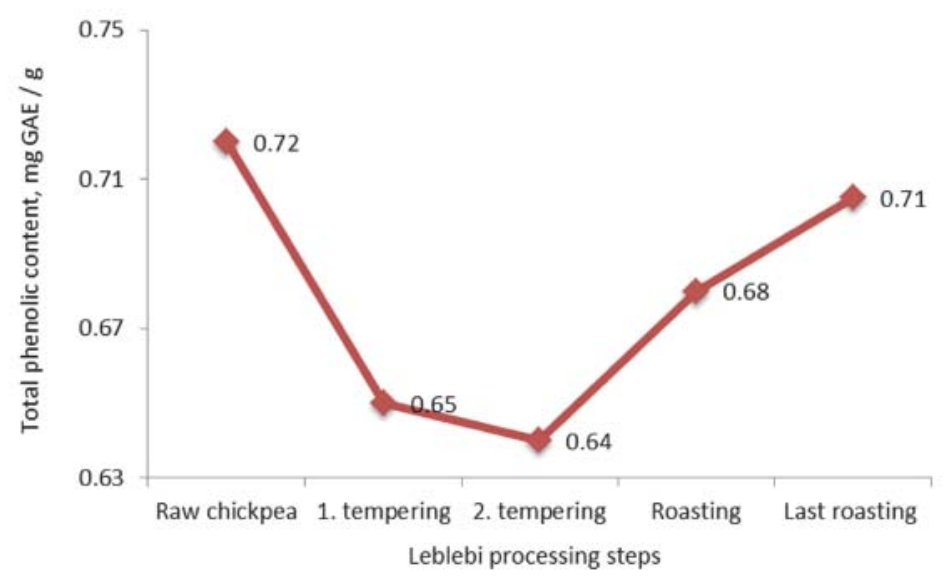

Fig. 2. Effect of leblebi processing on total phenolic content of chickpeas, \%, dry basis

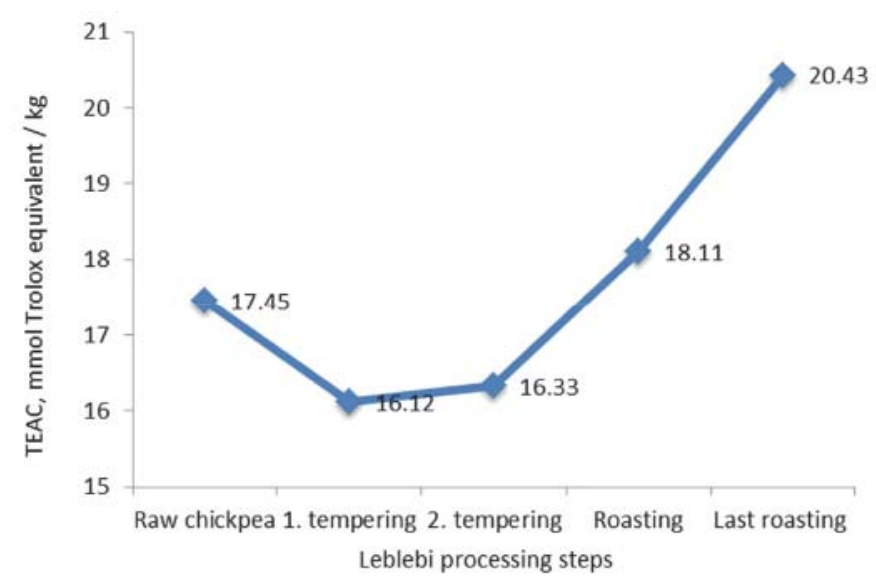

Fig. 3. Effect of leblebi processing on total antioxidant capacity of chickpeas, $\%$, dry basis

Finally, in some processed foods, e.g. roasted coffee, a significant portion of antioxidant compounds is formed due to Maillard reaction (Borelli et al., 2002; GöKMEN et al., 2009). The amounts of antioxidant capacity recommended daily intake is $400 \mathrm{mmol}$ Trolox equivalent $/ \mathrm{kg}$ in terms of the TEAC, therefore one portion leblebi $(100 \mathrm{~g})$ can supply nearly $20 \%$.

Minerals content of raw and processed chickpea samples are presented in Table 2. Analysis of variance showed that leblebi processing steps have significant $(\mathrm{P}<0.05)$ effects on mineral content. The process caused slight decrease in $\mathrm{Fe}, \mathrm{Zn}, \mathrm{K}, \mathrm{Na}, \mathrm{Mn}$, and $\mathrm{Mg}$ contents, but a high increase in $\mathrm{Cu}$ content (from 3.32 to $5.38 \mathrm{mg} \mathrm{kg}^{-1}$ ) was observed. Ca contents of chickpeas also decreased significantly (from 1277 to $678 \mathrm{mg} \mathrm{l}^{-1}$ ). The minerals could have drained from the chickpea into the water during leblebi processing steps at varying rates. 
These results are similar to findings of AlajaJI and El-Adawy (2006), that the nutritional compositions of chickpea were affected by traditional cooking method.

Table 2. Effect of leblebi processing on mineral contents of chickpeas

\begin{tabular}{lcccccccc}
\hline Sample & $\begin{array}{c}\mathrm{Cu} \\
\left(\mathrm{mg} \mathrm{kg}^{-1}\right)\end{array}$ & $\begin{array}{c}\mathrm{Fe} \\
\left(\mathrm{mg} \mathrm{kg}^{-1}\right)\end{array}$ & $\begin{array}{c}\mathrm{Zn} \\
\left(\mathrm{mg} \mathrm{kg}^{-1}\right)\end{array}$ & $\begin{array}{c}\mathrm{K} \\
\left(\mathrm{mg} \mathrm{kg}^{-1}\right)\end{array}$ & $\begin{array}{c}\mathrm{Na} \\
\left(\mathrm{mg} \mathrm{l}^{-1}\right)\end{array}$ & $\begin{array}{c}\mathrm{Mn} \\
\left(\mathrm{mg} \mathrm{l}^{-1}\right)\end{array}$ & $\begin{array}{c}\mathrm{Mg} \\
\left(\mathrm{mg} \mathrm{l}^{-1}\right)\end{array}$ & $\begin{array}{c}\mathrm{Ca} \\
\left(\mathrm{mg} \mathrm{l}^{-1}\right)\end{array}$ \\
\hline Raw chickpea & $3.32 \mathrm{~b}$ & $48.69 \mathrm{a}, \mathrm{b}$ & $56.62 \mathrm{a}$ & $8441 \mathrm{c}$ & $58.24 \mathrm{~b}$ & $16.49 \mathrm{~b}$ & $1151 \mathrm{~b}$ & $1277 \mathrm{~b}$ \\
1. Tempering & $3.50 \mathrm{~b}$ & $58.81 \mathrm{~b}$ & $52.44 \mathrm{a}$ & $6417 \mathrm{a}$ & $55.33 \mathrm{~b}$ & $16.36 \mathrm{~b}$ & $1108 \mathrm{~b}$ & $1278 \mathrm{~b}$ \\
2. Tempering & $2.63 \mathrm{a}$ & $57.19 \mathrm{~b}$ & $55.12 \mathrm{a}$ & $7381 \mathrm{~b}$ & $102.0 \mathrm{c}$ & $18.40 \mathrm{c}$ & $1031 \mathrm{a}$ & $635 \mathrm{a}$ \\
Roasting & $4.54 \mathrm{~b}, \mathrm{c}$ & $39.80 \mathrm{a}$ & $52.81 \mathrm{a}$ & $8319 \mathrm{c}$ & $52.25 \mathrm{~b}$ & $11.94 \mathrm{a}$ & $1400 \mathrm{c}$ & $758 \mathrm{a}$ \\
$\begin{array}{l}\text { Last roasting } \\
\text { (Dehulled leblebi) }\end{array}$ & $5.38 \mathrm{c}$ & $39.97 \mathrm{a}$ & $51.68 \mathrm{a}$ & $6985 \mathrm{a}, \mathrm{b}$ & $43.65 \mathrm{a}$ & $12.65 \mathrm{a}$ & $967 \mathrm{a}$ & $678 \mathrm{a}$ \\
\hline
\end{tabular}

*Values are means of duplicate analysis. Means in the same column with different letters are significantly $(\mathrm{P}<0.05)$ different.

Overall, leblebi processing showed no significant loss of proximate composition and total phenolic content, but reduced the moisture content. The observed results indicated that leblebi processing would result in considerable losses of carbohydrates, ash, and dietary fibre mainly due to the fact that the outer portions of chickpea containing cotyledon constituents were lost during dehulling operation of the roasting steps of leblebi production. The findings of this study demonstrate the nutritional consequences of the traditional leblebi processing steps used to convert chickpea into consumable forms.

\section{Conclusions}

Leblebi is widely consumed in Turkey as healthy traditional snack. In this study, chemical composition and nutritional changes during traditional leblebi processing were evaluated. Unlike many of its industrial sugary competitors, leblebi is a rich source of protein, dietary fibre, and minerals, and is low in fat and contains no sugar. Since it is whole grain with no further grinding, it has a very low glycemic index, thus it can be recommended as a health snack for longevity. In view of the overall nutrient and digestibility analysis, this traditional snack food product can be an economic and alternative protein source that would improve overall nutritional status in the world.

The author is grateful to Hitit University Scientific Research and Development Office for their financial support (Project no: MUH01.13.002) and also to Gülşen Food Corporate, (Çorum/Turkey) for kind donation of chickpea and leblebi samples.

\section{References}

AÇar, Ö.Ç., Gökmen, V., Pellegrini, N. \& Fogliano, V. (2009): Direct evaluation of the total antioxidant capacity of raw and roasted pulses, nuts and seeds. Eur. Food Res. Technol., 229(6), 961-969.

Alajaji, A.S. \& El-Adawy, A.T. (2006): Nutritional composition of chickpea (Cicer arietinum L.) as effected by microwave cooking and other traditional cooking methods. J. Food Compos. Anal., 19, 806-812. 
AOAC (2000): Official methods of analysis, $17^{\text {th }}$ ed., Washington, DC: USA. Method No. 990.03.

Borelli, R.C., Visconti, A., Mennella, C., Anese, M. \& Fogliano, V. (2002): Chemical characterization and antioxidant properties of coffee melanoidins. J. Agr. Food Chem., 50, 6527-6533.

CoȘKunER, Y. \& KARABABA, E. (2004): Leblebi: a roasted chickpea product as a traditional Turkish snack food. Food Rev. Int., 20(3), 257-274.

Costa, G.E.A., Oueiroz-Monici, K.S., Reis, S.M.P.M., \& Oliveira, A.C. (2006): Chemical composition, dietary fibre and resistant starch contents of raw and cooked pea, common bean, chickpea and lentil legumes. Food Chem., $94,327-330$

Cristobal, L.S., Osorio-Diaz, P., Tovar, J. \& Bello-Perez, LA. (2010): Chemical composition, carbohydrate digestibility, and antioxidant capacity of cooked black bean, chickpea, and lentil Mexican varieties. CYTA-J. Food, 8(1), 7-14.

FAO (2012): Food and Agricultural Organization of the United Nations, Statistical databases and data sets. Available from: http://www.faostat.fao.org/

Gökmen, V., Serpen, A. \& Fogliano, V. (2009): Direct measurement of the total antioxidant capacity of foods: the 'QUENCHER' approach. Trends Food Sci. Tech., 20, 278-288.

Iqbal, A., Khalil, I.A., Ateeq, N. \& Khan Ms. (2006): Nutritional quality of important food legumes. Food Chem., 97, 331-335.

Khattab, Y.R., Arntfielt, D.S. \& Nyachoti, M.C. (2009): Nutritional quality of legume seeds as affected by some physical treatments, Part 1: Protein quality evaluation. LWT-Food Sci. Technol., 42, 1107-1112.

Köksel, H., Sivri, D., Scanlon, M.G. \& Bushuk, W. (1998): Comparison of physical properties of raw and roasted chickpeas (leblebi). Food Res. Int., 31(9), 659-665.

Milan-Carillo, J., Reyes-Moreno, C. \& Armienta-Rodelo, E. (2000): Physicochemical and nutritional characteristic of fresh and hardened chickpeas (Cicer arietinum). LWT - Food Sci. Technol., 33, 117-123.

Mondor, M., Aksay, S., Drolet, H., Roufik, S., Farnworth, E. \& Boye, J.I. (2009): Influence of processing on composition and antinutritional factors of chickpea protein concentrates produced by isoelectric precipitation and ultrafiltration. Innov. Food Sci. Emerg., 10, 342-347.

Rehinan, Z., Rashid, M. \& Shah, H.W. (2004): Insoluble dietary fibre components of food legumes as affected by soaking and cooking processes. Food Chem., 85, 245-249.

Rehman, Z., Islam, M. \& Shah, W.H. (2003): Effect of microwave and conventional cooking on insoluble dietary fibre components of vegetables. Food Chem., 80, 237-240.

Rehman, Z. \& Shah, W.H. (2004): Domestic processing effects on some insoluble dietary fibre components of various food legumes. Food Chem., 87, 613-617.

Rzedzicki, Z., Domanska, E.S. \& Popielewicz, J. (2008): Quality of wheat breakfast cereals available on the Polish market. Pol. J. Food Nutr. Sci., 58(3), 307-312.

Serpen, A., Capuano, E., Fogliano, V. \& GöKmen, V. (2007): A new procedure to measure the antioxidant activity of insoluble food components. J. Agr. Food Chem., 55, 7676-7681.

Singh, U., Rao, V.P. \& SeEtha, R. (1992): Effect of dehulling on nutrient losses in chickpea (Cicer arietinum L.). J. Food Comp. Anal., 5, 69-76.

Singleton, V.L. \& Lamuela-Raventos, R.M. (1999): Analysis of total phenols and other oxidation substrates and antioxidants by means of Folin-Ciocalteu reagent. Method. Enzymol., 299, 152-178.

Singleton, V.L. \& Rossi, J.A. (1965): Colorimetry of total phenolics with phosphomolybdic-phosphotungstic acid reagents. Am. J. Enol. Viticult., 16, 144-158.

Tharanathan, N.R. \& Mahadevamma, S. (2003): Garin legumes - a boon to human nutrition. Trends Food Sci. Tech., 14, 507-518.

USDA (2007): The food supply and dietary fiber: Its availability and effect on health. United States Department of Agriculture Centre for Nutrition Policy and Promotion, Nutrition Insight 36, 2 pages.

Vadivel, V., Nandety, A. \& Biesalski, K.H. (2011): Antioxidant potential and health relevant functionality of traditionally processed Cassia hirsute L. seeds: An Indian underutilized food legume. Plant Foods Hum. Nutr., $66,245-253$

Vega, C.R., Guadalupe, L-P. \& Oомah, D.B. (2010): Minor components of pulses and their potential impact on human health. Food Res. Int., 43, 461-482.

Wang, N., Hatcher, D.W., Tyler, R.T., Toews, R. \& Gawalko, E.J. (2010): Effect of cooking on the composition of beans (Phaseolus vulgaris L.) and chickpeas (Cicer arietinum L.). Food Res. Int., 43, 589-594. 